\title{
Youth Empowerment, Wealth Creation and Security as Key to National Development
}

\author{
Grace Ifeoma Egwu \\ http://dx.doi./org/10.4314/ujah.v21i3.5
}

\begin{abstract}
This paper examined youth empowerment, wealth creation and security as key to national development. The paper was guided by three objectives viz-a-viz; finding out how the empowerment of youth enhances national development, determining how wealth creation in the country is capable of enhancing national development and examining the role security play in entrenching national development. Reviews of literature were carried out in line with the objectives of the study using secondary data as method of data collection. The paper concluded that youth empowerment, wealth creation and national security enhance a nation's positive and sustainable development. The paper suggested that government should make youth empowerment and wealth creation process in the country seamless so that majority of her unemployed youth can key into the scheme to uplift self and enhance national development. Also, the government should make national security a priority at all times. This is because without adequate security in the country, the zeal to be creative will be discouraged, investment will be limited, thus making development of the country to be stagnated as interested persons and organizations will be scared to invest.
\end{abstract}

Keywords: Youth Empowerment, Wealth Creation, Security, National Development 


\section{Introduction}

For a nation to be developed, the means to actualize such intention should be made available for its easy harnessing in a bid to afford every citizen the right to achieve and contribute to societal development. In the light of this, it is imperative that a nation aspiring for development makes the environment conducive and friendly for the actualization of stated objective. The creating of conducive environment in this context entails the presence of diverse positive means that supports wealth creation and assured of security of lives and property. The imperative of wealth creation and security will ensure that a national achieve its desired growth and development. The presence of security in a country ensures that citizens undertake legitimate means of livelihood that by extension leads to growth and development of Nigeria. Security here entails that there is no needless apprehension when entrepreneurs who are wealth creators engage in their entrepreneurial activities in the country. The presence of security fosters confidence in the citizens and ensures that they are willing to contribute their quota to the country thus expediting national development.

Nigeria is the most populous nation in Africa. Nigeria is blessed with abundant human and natural resources spread throughout the country. In spite the fact that the nation is endowed with these resources, Nigeria is still struggling to be developed and be a power to be reckoned with in the community of nations. The problem of the continuous increase in poverty, armed robbery, militancy in the Niger Delta region, herdsmen/farmers crisis and Boko Haram disturbances in the Northern region may not be unconnected to the fact that majority of Nigeria youths are not empowered to contribute meaningfully to national development (Nnachi, 2012). Their belief of the youths is that the nation has failed them and therefore, they are paying back to the country what they felt was given to them. Unfortunately, most of our tertiary institutions turn out graduates on 
Egwu:Youth Empowerment, Wealth Creation and Security as Key to National Development

yearly basis without a corresponding job creation to take care of them (Nnachi, 2012).

According to statistics from the Nigerian Bureau of Statistics (NBS) (2009), Nigeria's unemployment rate is at 23.9 per cent and 60 per cent of its population are youths, translating to about 80 million Nigerian youths. Youth unemployment rate is over 50 percent, about 64 million Nigerian youths are unemployed. This scourge of unemployment has deprived many Nigerian youths access to contributing their quota to national development. The result of the rising youth unemployment situation in the country has provided shrinking options to job seekers as those who find work are forced to be less selective about the type of job they settle for, including parttime work and temporary contracts because they are in desperate need for any income. Undoubtedly, the challenges for youths that are central to Africa's economic development are numerous and varied they include employment, health and political participation. These issues differ among groups within countries (by gender, education level, ethnicity and health status), and across countries and regions. Conversely, the size, energy, enthusiasm, innovation and dynamism of youths are assets that can be harnessed for Africa's development with appropriate policies that deal adequately with the issues facing them.

Despite the elevated awareness of the challenges confronting Nigerian and Africa's youths noted by previous studies, several African countries like ours still do not seem to have developed comprehensive and effective policies to deal with the issues facing this large and growing segment of the African population or to have in place a means to assess the progress made. The purpose of this study is to advance the discussion of the problems facing youths in Africa by assessing whether African countries' existing youths' policies can meet the challenges and how these policies can be improved to foster the continent's equitable and efficient development 
in general and Nigeria in particular. The National Youth Policy is full of platitudes and little has been done to bring it into full implementation despite several reviews of the policy since its formulation in 1981. Admittedly, the Federal Government noted that policy attempts hardly provided a concrete framework for addressing the heightened problems confronting the youth in the 1990's. This was partly because the implementation mechanisms of the policy were weak and ineffective (SNYPD, 2009)

Bondzi-Simpson (2011) was therefore right to have asserted that enforcement challenge undermines the rate of development in most African states. Until 2007, there was no separate ministry for youth development in the country. Governments at all levels have continued to lay claim to several jobs created. Yet, the jobs are nowhere to be found by the massive youth. Dwindling economy resulting from corrupt practices (Okorie, 2011), lack of entrepreneurial skills (Alao, 2013), job creations, marketable and productive skills (Agholor et al., 2013) have all been identified as the root causes of youth unemployment.

\section{Objectives of the Study}

The following objectives guided the study

i. To find out how the empowerment of youth enhances national development

ii. To determine how wealth creation in the country is capable of enhancing national development

iii. To examine the role of security in national development

\section{Youth Empowerment and National Development}

It is significant to define who a youth is though there seems no general definition of who a youth is as the term is used differently by individuals, governments and non-governmental organizations. However, the United Nations and Common Wealth of Nations have 
Egwu:Youth Empowerment, Wealth Creation and Security as Key to National Development

come up with specific age categories to define a youth. Perhaps, that informed Echebiri (2005) in Nnachi (2012) to indicate that, the United Nations uses age category 15 -24 years to define a youth, while the common wealth uses the age category of 15-29. Most countries have either adopted the UN or common wealth definition. However, in Nigeria, the range is 15-36 years has been taken to be the youth category. Youth empowerment is inventiveness with a view to re-engineering their potentials and energies for peace and stability to lessen poverty, un-employment and criminality. To support this view, Chikamnayo (2013) opined that, self-employment is being driven to the zenith by training and equipping youths with both financial support and the asset base to enhance the growth of their businesses. $\mathrm{He}$ added further that, the interventionist programme in Abia State has attained enviable height in peace and security management.

In the same vein, National Economic Empowerment and Development Strategy (NEEDS) (2005) accentuate in its thrust towards empowering people to improve lives through plans for creating jobs, strengthening the skill base, protecting the weak and promoting peace and security. This is a move toward stopping all sorts of marginalisation and neglect against the youths and to give them the same opportunity and access to education, financial control, political participation, leadership etc. regardless of gender or educational level. Economic empowerment enables the youths to take informed decision on how to fix their life-long experience and selfdevelopment by it. The youth form the pivot trustees and occupy core centre of the politico-economy of a nation. A youth in Nigeria may be described as being energetic, full of life, vigor, stamina, vitality and endowed with drive and fearless, irrespective of worldwide perception of Nigerian youth as lazy. These potentials and inventiveness, if not directed towards productive ventures, could be used negatively to disrupt social, economic and political structures. According to Agholor, Afatakpa and Kent-Onah, (2011) youthful age 
is between ages $1-45$ years, the most viable stage in the life of humans. If individuals at this stage of development are not occupied by positive activities, the tendencies to take to negative vices will be extremely high. However, graduates of tertiary institutions also seem to be badly hit by unemployment too; making up about 20 percent of youth unemployment and often remaining unemployed for upward of five years after graduation due to unavailability of jobs and stringent employment criteria needed from the youth before being employed in organizations, including government owned once (World Bank).

\section{Wealth Creation and National Development}

Wealth creation is a term often used by economists and very important in development theory but which is very ambiguous if not properly explained. However, explanation of wealth creation elicits a corresponding understanding of the meaning of wealth especially as it affects this investigation. Adam Smith, the leading economist and author of The Wealth of Nations, described wealth as the annual produce of the land and labour of the society. This "produce" is at its simplest form that which satisfies human needs and wants of utility (Ojenike et al., 2014). In popular economic usage, wealth can be described as an abundance of items of economic value, or the state of controlling or possessing such items, usually in the forms of money, real estate and personal property (Ojenike et al., 2014). Wealth therefore, refers to the net worth of a person, household, or nation, that is, the value of all assets owned net of all liabilities owed at a point in time. There is no fundamental difference in explaining the concept of wealth in economic and political viewpoints. Though in political term, wealth may be used more broadly as referring to the productive capacity of a society or as a contrast to poverty. To this end, wealth may involve both one's state of health, economic wellbeing and other accruing social benefits. Indeed, wealth provides 
Egwu:Youth Empowerment, Wealth Creation and Security as Key to National Development

an important mechanism in the intergenerational transmission of inequality (Gilbert, 2002).

Wealth is a tool for measuring both social stratification and class division in a society. Perhaps, from the foregoing, explanation of wealth, wealth creation may be seen as the combination of materials, labour, land and technology in a way as to capture a profit (that is, excess above the cost of production) (Smith as cited in Gilbert, 2002). There are different types of wealth creation: national, social and individual wealth creations. However, whether national, social or individual, wealth creation entails man's ability to combine the productive forces in reaching his utmost end that will advance societal development. Productive forces here consist of labour power, objects of labour and instruments of labour (Ake, 2001).Accordingly, wealth creation has to do with production and distribution of material means of existence. Those who produce in large quantity far beyond what is necessary for their sustenance are said to be creating more wealth than those not so favourably disposed to production beyond their daily needs. The basis of societal development is dependent upon the ability of such society in creating wealth as this will ensure that her citizens are productively involved thus limiting the adverse effect of lack which has security implications. Central to wealth creation therefore, are employment generation, poverty reduction, disease control, disaster management and crime guard as these are vices that if not properly tackled and managed in the society has the tendency of metamorphosing into chaos of monumental proportion with adverse security implication.

\section{Security and National Development}

Security entails absence of fear and violence. Security is as old as the history of man. Security is a cherished value associated with the physical safety of individuals, groups or nation-states, together with a similar safety of their other most cherished values (Nnoli, 2006). It is 
measured in both objective and subjective senses with threat, anxiety and danger as the explanatory variables. In objective sense, security can be seen as the absence of threat, anxiety or danger (Nnoli, 2006). However, it is very difficult to measure what fits into threat, anxiety or danger; thus, it is better understood as freedom from or absence of violence, war, and other forms of physical attacks. Once a society if free from these variables, then that society is said to enjoy security in objective sense, notwithstanding whether there is threat of their possible occurrence in the future. To this end, every state whether those of Afghanistan, Iraq, Yemen, Somalia, among others where crisis is common, insofar as they are not fighting for the moment, is said to be secured in objective sense. However, understanding security in objective sense alone is self-defeatist because it could be misleading. Misleading in the sense that, a society with possible threat of violence, war, and other forms of physical attacks, even though might be enjoying peace of the grave-yard, cannot be said to be a secured society as objective security would want us to believe; hence, the need to explain security beyond the objective sense. Very importantly, in subjective sense, Nnoli (2006) asserts that "security can be measured by the absence of fear that threats, anxiety or danger will materialize". In other words, it is a value associated with confidence in physical safety and other cherished values. The implication of this is that, whether there is an impending possible attack of whatever nature, insofar as the people have the confidence that the attack(s) will not materialize, such a people is said to enjoy security.

Consequently, in both objective and subjective senses, no country is completely secured if at all so. Therefore, security is a relative term, highly ambiguous and difficult to operationalize. However, within the context of this paper, security can be defined as the existence of physical safety either of economic well-being or military might, as well as the conviction that upon the existence of 
social vices whether hunger, poverty, unemployment and crime, the state would be readily available to repel them within the shortest possible timeframe. Viewed accordingly, security becomes measurable and possible to study. The implication of the foregoing is that, security is a network of communication that goes beyond the availability of military strength for fighting crimes in a society to incorporating other non-combatant social situations like economic wellbeing, good health system, and functional educational system, among others. Crime is not the only variable that makes a society insecure. In fact, poverty plays a pivotal role in making a society vulnerable for security questions.

\section{National Youth Empowerment Strategies in Nigeria}

The following amongst others are strategies employed for the empowerment of youth in the country:

\section{Millennium Development Goals (MDGs) Later Sustainable Development Goals (SDGs)}

At the September 2000 United Nations Millennium Summit, world leaders adopted the Millennium Declaration and a set of accompanying Millennium Development Goals (MDGs) aimed at reducing poverty, hunger, disease, illiteracy etc. by 2015, but due to various issues ranging from policy implementation to finance, commitment of host country amongst others, the MDGs were unable to meet its target thus giving way for the SDGs that has 17 global goals aimed at consolidating the achievement of the MDGs. The SDGs are part of the Resolution 70/1 of the United Nations General Assembly with 2030 as its target year for the elimination of global poverty and hunger. These goals amongst others makes developing countries, Nigeria inclusive to be able to develop and implement policies that are amongst others social in nature aimed at empowering citizens to tackle the issue of poverty and hungers; thus by extension 
creating wealth, discouraging negative vices and enhances national development.

\section{The Graduate Internship Scheme (GIS)}

This was introduced as a youth empowerment strategy in collaboration with Subsidy Reinvestment and Empowerment Programme (SURE-P) and the recently added N-Power to provide skills and knowledge that will pilot economic growth and social development of the country. These schemes are aimed at addressing the challenges of youth unemployment by providing a structure for large scale and relevant work skill acquisition and development, while linking its core and outcome to fixing inadequate public service and stimulating the larger economy for national development. Primarily, it seeks to provide un-employed graduate youths with job apprenticeship opportunities that would expose them to skills and experiences relevant to current labour market and enhance their employability (Achumba et al., 2013).

\section{Conclusion}

The study is on youth empowerment, wealth creation and security as key to national development. In examining the effect of the variables of the study and their effect to national development, the paper made use of secondary data to arrive at the conclusion that, youth empowerment, wealth creation and national security enhance a nation's positive and sustainable development. Thus, for a nation to attain great height, she cannot afford to malign youth empowerment, wealth creation amongst youth and security in the country.

\section{Recommendation}

Arising from the conclusion, the paper suggested that:

i. Government should make youth empowerment and wealth creation process in the country seamless so that majority of her 
Egwu:Youth Empowerment, Wealth Creation and Security as Key to National Development

unemployed youth can key into the scheme to uplift self and enhance national development

ii. Government should make national security a priority at all times. This is because without adequate security in the country, the zeal to be creative will be discouraged, investment will be limited thus making development of the country to be stagnated as interested persons and organizations will be scared to invest.

\section{Grace Ifeoma Egwu, PhD Department of Social Studies College of Education, Agbor Delta State egwugrace089@gmail.com}

\section{References}

Achumba, I.C., Ighomereho, O. S., \& Akpan-Robaro, M. O. M. (2013). Security challenges in Nigeria and the implications for business activities and sustainable development. Journal of Economics and Sustainable Development, 4(2), 79-99.

Agholor, J., Afatakpa, O.L., \& Kent-Onah, R. (2011). Poverty alleviation through skill acquisition for entrepreneurship development in Nigeria. Okene Vocational Education Journal 1 (1) 6

Ake, C. (2001). Political Economy of Africa. Nigeria: Longman Nigeria Ltd

Alao I. (2013) "Does the Nigeria education system prepare students for the work environment", Naija Writers' Coach Essay Contest. Available online at http://www.naijawriterscoach.com/entry

Bondzie-Simpson, (2011). Green jurisprudence: Law's place in sustainable development" being a paper delivered at conference on the theme "Law and Sustainable Development" 
organized by the Faculty of Law, University of Ilorin, Ilorin, Kwara State, 6-9 November, 2011.

Chikamnayo, E. (2013). The role of NEVT programme for improving skill acquisition for youth empowerment in Nigeria. Okene Vocational Education Journal 1 (1), 94

Echebiri, R.N. (2005), Characteristics and determinants of urban youth unemployment in Umuahia, Nigeria: Implications for rural development and alternative labour market.

Gilbert, D. (2002). The America class structure in an age of growing inequality. N.P: Wadsworth Publishing

National Bureau of Statistics. (2009). Social statistics in Nigeria. Abuja: The NBS Publication.

National Economic Empowerment and Development Strategy (NEEDS) (2005). Empowerment. Retrieved $7^{\text {th }}$ October 2019 from www.data.worldbank.org

Nnachi, A.N. (2012). "Youth Employment: A bane to the actualization of the Nigerian government 7-point agenda" Journal of Arts and Social Nigeria Government, 1 (2), 263 267.

Nnoli, O. (2006). Path to Nigerian development, Dakar: CODESRIA

Ojenike, B., Adedokun S.O., Odunsi A.O. \& Ojenike, J.O. (2014). Challenges of communication strategies for sustainable national development in Nigeria. Journal of Media and Communication Studies, 6(3), 43-47

Okorie, I. (2011). "Insecurity consequences for investment and employment". The Punch Newspaper, Tuesday 16

Second National Youth Policy Document (SNYPD) of the Federal Republic of Nigeria 2009". Available online at http://www.youthpolicy.org

World Bank. (1998), World development indicators. Washington, D.C.: World Bank 